\title{
Effect of Ascorbic Acid Foliar Application on Yield, Yield Component and several Morphological Traits of Grain Corn under Water Deficit Stress Conditions
}

\author{
Aria DOLATABADIAN ${ }^{11}$, Seyed Ali Mohammad MODARRES SANAVY'1), Kamal Sadat ASILAN ${ }^{22}$ \\ ${ }^{1)}$ Tarbiat Modares University, Faculty of Agriculture, Agronomy Department, Tehran, Iran; modaresa@modares.ac.ir \\ ${ }^{2)}$ Payame Noor University, Karaj, Iran
}

\begin{abstract}
In order to study effect of ascorbic acid foliar application on morphological traits, yield and yield components of grain corn under conditions of water stress, an experiment was conducted in Tarbiat Modares University, Tehran, Iran in 2006 growing season. Experimental design was RCBD (Randomized Complete Block Design) and treatments were sat in split-split plot arrangement. Water deficit stress treatment with three levels (no stress, vegetative phase stress and reproductive phase stress) was allocated to main plots. Ascorbic acid was used at two time (vegetative phase and reproductive phase) and four concentration (0, 50, 100 and $\left.150 \mathrm{mgl}^{-1}\right)$ as sub plots and sub-sub plots, respectively. The results demonstrated that water deficit stress and ascorbic acid foliar application had significant effect on upon traits. Water deficit stress significantly decreased dry or fresh weight of plants at two growing phases, but leaf area was just decreased due to water deficit stress at vegetative phase. Regarding yield and yield components, a significant decrease was observed when plants were water stressed. It's notable that final yield was more affected when plants were stressed at reproductive phase than those were stressed at vegetative phase. Ascorbic acid foliar application increased stem and leaf dry weight and leaf fresh weight. In addition, an increase was observed in grain weight when plants were treated by $150 \mathrm{mgl}^{-1}$ ascorbic acid at two growing phases and no stress and vegetative stress. The highest infertile grains were observed in reproductive stress and without ascorbic acid plots while ascorbic acid foliar application led to increase of grain fertility. In general, these results suggests that ascorbic acid foliar application decreases adverse effects of water deficit stress and improves growth and production at normal and stressed conditions.
\end{abstract}

Keywords: ascorbic acid, corn, water deficit stress, yield and yield components

\section{Introduction}

Water deficit stress is one of the most important environmental stresses that limit crop growth and agricultural products. In addition, drought and water deficit stress had several effects on agricultural and ecological systems (Rochefort and Woodward, 1992). On the other hand, water stress limits corn production in many places of the world yearly. Yield loss occurs when crop is exposure to water deficit stress, especially when plants are at flowering or reproductive phases (Saini and Westgate, 2000). It's possible that water deficit stress happens before or after flowering stage also drought resistance can be raised in each growing phases.

Abiotic stresses for example drought, salinity, heat, cold and even biotic stresses such as pests and diseases induces the generation of reactive oxygen species (ROS) causing lipid peroxidation which leads to membrane injury, protein degradation, enzyme inactivation and the disruption of DNA strands. These free radicals may cause oxidative stress resulting in cellular damage by oxidation of lipids, proteins and nucleic acids (Noctor and Foyer, 1998). Plants possess efficient systems for scavenging ROS that protect them from destructive oxidative reactions. These systems are consist non-enzymatic and enzymatic antioxidant systems such as carotenoids ascorbic acid tocopherols, peroxidase and catalase (Munne-Bosch and Alegre, 2000; Asada, 1999). It has been reported that there are correlations between antioxidants in cells and water deficit stress (Tsugane et al., 1999). One approach for inducing oxidative stress tolerance would be to increase the cellular level of enzyme substrates such as ascorbic acid (vitamin C). Ascorbic acid is a small, water-soluble anti-oxidant molecule which acts as a primary substrate in the cyclic pathway of enzymatic detoxification of hydrogen peroxide. Ascorbic acid is the first substance in detoxification and neutralizing of super oxide radicals (Noctor and Foyer, 1998). Also, latter has important role in vital process in plant growth such as cell division and cell wall expansion (Pignocchi and Foyer, 2003). Moreover, ascorbic acid plays important role in ascorbate-glutathione pathway and scavenges ROS in chloroplast (Foyer and Harbinson, 1994) and cytosol (Asada, 1999).

Grain yield in maize is strongly correlated with yield components and it's reported that any reduction in the 
46

yield components lead to a reduction in the final yield (Otegui, 1995).

Seed setting had high sensitivity to environmental conditions and especially tasseling and silking stages are high sensitive stages to water stress and deficiency (Tollenaar, 1977). Water stress like other environmental stresses caused production of oxygen free radicals in the plant. These free radicals destroy biological molecules and lead to abnormal physiological and metabolic processes of plant. Saini and Westgate (2000) have been reported that different reproduction stages in corn had especial sensitivity to water stress. Also, two weeks after pollination until physiological maturity is the most sensitive stages to water stress and occur of water stress in this period significantly decreases grain weight (McPherson and Boyer, 1977). It's reported that critical period to water stress in corn initiates from two weeks before silking and last two or three weeks after that (Fischer and Palmer, 1984).

Water stress, increases interval between tasseling and silking and thus number of grains and yield will be decreased (Edmeades et al., 1993).

The objective of this experiment is study on morphological traits, yield and yield component of grain corn affected by water deficit stress and ascorbic acid as antioxidant molecule.

\section{Material and methods}

The experiment was conducted on the research farm of Faculty of Agriculture, Tarbiat Modares University, Tehran, Iran $\left(35^{\circ} 41^{\prime} \mathrm{N}\right.$ latitude, $51^{\circ} 19^{\prime} \mathrm{E}$ longitude and altitudes of $1215 \mathrm{~m}$ ) during 2006 growing season. After seed bed preparation and before planting, the soil surface of the cultivated area was thoroughly irrigated then seeds of grain corn (Zea mays S. C. 704) were hand sown on $3 \times 4 \mathrm{~m}$ plots on 15 May 2006. Seeds were sown at $3 \mathrm{~cm}$ depth in middle of rows, with $0.7 \mathrm{~m}$ between rows and $0.25 \mathrm{~m}$ within rows ( 5 rows). This was provided a population density of about 6.6 plants $\mathrm{m}^{-2}$. The experimental design was a randomized complete block with a split-split plot arrangement of treatments in three replications. The treatments were three levels of water stress; irrigation at field capacity (no stress), water stress at vegetative phase (eight leafy stages) and water stress at reproductive phase (tasseling). Water stress was initiated by withholding of irrigation until soil moisture was decreased to $70 \%$ of field capacity. Soil moisture was monitored by Time Domain Reflectometry (TDR, FMTrime-IMKO-Gmbh, D-76275-Germany) method. Also, polyethylene pipeline and installation of counter was performed for control of irrigation. Different water stress levels were allocated to main plots and ascorbic acid was used at two time (vegetative phase and reproductive phase) and four concentration $\left(0,50,100\right.$ and $\left.150 \mathrm{mgl}^{-1}\right)$ as sub plots and sub-sub plots, respectively. In ascorbic acid treatment plots, the whole shoots of plants were foliar fertilized with different concentration of ascorbic acid solution by a cali- brated pressurized backpack sprayer (20 l capacity). For the control treatment, plants were sprayed with water. Foliar application of ascorbic acid was performed at the end of water stress treatments and following foliar application irrigation was done. Weed control was realized manually without any chemical input. According to results of soil analysis nitrogen was used from urea (400 $\mathrm{kgha}^{-1}$ urea), but it was needed no fertilizer such as P, K. Urea was applied at three times included sowing time, six leafy stage and tasseling stage.

After treatment application five representative plants per plot were sampled and brought to the laboratory, where the leaves, stems, and inflorescences were separated and the green leaf area was measured using a leaf area meter (Area Measurement System, DELTA-T, Cambridge, UK). Stem and leaf fresh weigh were measured and then samples were dried at $75^{\circ} \mathrm{C}$ and then dry weigh was measured again. After the maize reached physiological maturity (R6), a $5.0-\mathrm{m}$ stretch of plants from two adjacent rows (rows 3 and 4 ) were hand-harvested from each plot. All ears were harvested, the ears were dried at $75^{\circ} \mathrm{C}$, some traits related to yield components such as 100 grain weight, numbers of grain in row, number of row were measured and then the grains were manually removed from the cobs. Cob weight, diameter of cob, length of infertile grains, ear diameter, ear length and ear weight were registered too. The dry grain was weighed, and yields were calculated on $14 \%$ moisture content. Grain oil and protein percentage were measured by Inframatic 8620 Percor.

The data were analyzed by analysis of variance using the general linear model procedure in the Statistical Analysis System (SAS). Duncan's Multiple Range Tests was used to measure statistical differences between means.

\section{Results and discussions}

Analysis of variance showed that water deficit stress had significant effect on all measured traits (Tab. 1). Also effect of ascorbic acid was significant on all of traits except for number of leaves, plant height and protein percentage (Tab. 1). While time of foliar application was just significant on cob weight and ear weigh (Tab. 1). Interaction between water stress and time and also time and ascorbic acid concentration were significant on number of rows and 100 grain weighs, respectively (Fig. 1 and Fig. 2).

It was observed that interaction between water stress and ascorbic acid concentration was significant in respect of stem dry weigh, plant height, 100 grain weight, diameter of cob, number of grain in rows, length of infertile grain, ear diameter, ear weight and oil percentage (Tab. 2). There was not any significant interaction between water stress and time of application. According to Tab. 3, there was significant difference among different levels of water stress on most traits except for leaf fresh weight and leaf number. Water stress reduced stem dry weight and leaf dry weight when it was induced before and after flowering 
Tab. 1. Analysis of variance on morphological traits, yield and yield component of grain corn under conditions of water deficit stress and ascorbic acid foliar application

\begin{tabular}{|c|c|c|c|c|c|c|c|c|c|c|c|}
\hline S.O.V & d.f & $\begin{array}{c}\text { Stem dry } \\
\text { weight }\end{array}$ & $\begin{array}{c}\text { Leaf dry } \\
\text { weight }\end{array}$ & $\begin{array}{c}\text { Stem fresh } \\
\text { weight }\end{array}$ & $\begin{array}{c}\text { Leaf fresh } \\
\text { weight }\end{array}$ & $\begin{array}{c}\text { Leaf area } \\
\text { index }\end{array}$ & $\begin{array}{l}\text { Number } \\
\text { of leaves }\end{array}$ & Height & Grain yield & $\begin{array}{c}\text { 100grain } \\
\text { weight }\end{array}$ & $\begin{array}{c}\text { Cob } \\
\text { weight }\end{array}$ \\
\hline $\mathrm{R}$ & 2 & 2623.68 & 252.71 & 17750.94 & 105.91 & 1112604.04 & 12.01 & 5.34 & 7620.18 & 3.85 & 82.14 \\
\hline $\mathrm{D}$ & 2 & $8302.07^{* *}$ & $213.98^{* *}$ & $25633.91^{* *}$ & $5633.09^{* *}$ & $7599323.51^{* *}$ & $24.66^{*}$ & $5139.40^{* *}$ & $104636096^{* *}$ & $603.75^{* *}$ & $1352.60^{* *}$ \\
\hline $\mathrm{D} \times \mathrm{R}$ & 4 & $1137.88^{*}$ & 24.77 & $4661.76^{*}$ & $1121.46^{* *}$ & $573691.16^{*}$ & $19^{*}$ & 32.05 & 2040.82 & $7.95^{* *}$ & 41.90 \\
\hline $\mathrm{T}$ & 1 & 54.28 & 0.38 & 117.65 & 14.83 & 101198.26 & 0.55 & 49.46 & 928.08 & 0.46 & $94.76^{*}$ \\
\hline $\mathrm{T} \times \mathrm{D}$ & 2 & 975.81 & 15.85 & 940.58 & 39.97 & 303387.74 & 0.27 & 35.27 & 443.40 & 0.14 & 7.28 \\
\hline $\mathrm{T}(\mathrm{D}) \times \mathrm{R}$ & 6 & 836.92 & 11.13 & $4599.42^{*}$ & $420.05^{*}$ & 185451.32 & 0.32 & 41.16 & 548.33 & 0.91 & 16.96 \\
\hline C & 3 & $2326.40^{* *}$ & $99.72^{* *}$ & $9248.61^{* *}$ & $5131.46^{* *}$ & $2352974.98^{* *}$ & 6.6 & 40.56 & $11086.29^{* *}$ & $325.07^{* *}$ & $185.96^{* *}$ \\
\hline $\mathrm{C} \times \mathrm{D}$ & 6 & $1150.62^{*}$ & 15.05 & 3467.92 & 277.61 & 99160.20 & 10.23 & $338.48^{* *}$ & 1930.87 & $29.16^{* *}$ & 26.09 \\
\hline $\mathrm{C} \times \mathrm{T}$ & 3 & 896.98 & 15.45 & 1704.10 & 36.53 & 13239.46 & 0.25 & 102.04 & 2039.58 & $11.24^{* *}$ & 16.88 \\
\hline $\mathrm{C} \times \mathrm{T} \times \mathrm{D}$ & 6 & 424.55 & 15.05 & 1307.02 & 118.25 & 133351.23 & 0.11 & 28.69 & 908.70 & 2.48 & 9.56 \\
\hline E & 36 & 393.59 & 15.58 & 1721.62 & 159.03 & 159916.24 & 5.95 & 78.80 & 1142.47 & 1.87 & 16.74 \\
\hline CV\% & & 18.33 & 9.43 & 10.77 & 10.07 & 8.75 & 20.80 & 5099 & 12.73 & 4.82 & 11.35 \\
\hline S.O.V & d.f & $\begin{array}{c}\text { Diameter } \\
\text { of cob }\end{array}$ & $\begin{array}{l}\text { Number } \\
\text { of grain } \\
\text { in row }\end{array}$ & $\begin{array}{c}\text { Number } \\
\text { of row }\end{array}$ & $\begin{array}{c}\text { Length of } \\
\text { infertile } \\
\text { grains }\end{array}$ & $\begin{array}{c}\text { Ear } \\
\text { diameter }\end{array}$ & $\begin{array}{c}\text { Ear } \\
\text { length }\end{array}$ & $\begin{array}{c}\text { Ear } \\
\text { weight }\end{array}$ & Oil \% & $\begin{array}{c}\text { Protein } \\
\%\end{array}$ & \\
\hline $\mathrm{R}$ & 2 & 1.38 & 35.35 & 1.05 & 0.06 & 12.04 & 5.28 & 2337.45 & 0.71 & 0.19 & \\
\hline $\mathrm{D}$ & 2 & $82.23^{* *}$ & $739.44^{* *}$ & $2.25^{* *}$ & $6.40^{* *}$ & $139.10^{* *}$ & $94.03^{* *}$ & $29988.10^{* *}$ & $12.96^{* *}$ & $4.17^{* *}$ & \\
\hline $\mathrm{D} \times \mathrm{R}$ & 4 & 1.40 & 3.72 & $2.09^{* *}$ & 0.07 & 2.19 & 1.71 & 716.09 & 0.46 & 0.11 & \\
\hline $\mathrm{T}$ & 1 & 0.001 & 37.84 & 0.11 & 0.25 & 1.003 & 1.77 & $1855.16^{*}$ & 0.03 & 0.02 & \\
\hline $\mathrm{T} \times \mathrm{D}$ & 2 & 0.45 & 4.25 & $1.20^{*}$ & 0.19 & 2.13 & 1.009 & 329.55 & 0.26 & 0.02 & \\
\hline $\mathrm{T}(\mathrm{D}) \times \mathrm{R}$ & 6 & 1.53 & 12.41 & 0.57 & 0.01 & 2.17 & 0.95 & 752.80 & 0.06 & 0.07 & \\
\hline C & 3 & $35.76^{* *}$ & $105.85^{* *}$ & $2.01^{* *}$ & $0.85^{* *}$ & $34.14^{* *}$ & $70.93^{* *}$ & $5853.94^{* *}$ & $1.92^{* *}$ & 0.14 & \\
\hline $\mathrm{C} \times \mathrm{D}$ & 6 & $8.55^{* *}$ & $28.50^{*}$ & 0.39 & $0.44^{* *}$ & $15.91^{* *}$ & $5.66^{* *}$ & $1136.83^{*}$ & $1.12^{* *}$ & 0.23 & \\
\hline $\mathrm{C} \times \mathrm{T}$ & 3 & 0.30 & 13.81 & 0.49 & 0.09 & 2.97 & 2.93 & 759.47 & 0.05 & 0.11 & \\
\hline $\mathrm{C} \times \mathrm{T} \times \mathrm{D}$ & 6 & 0.76 & 4.12 & 0.31 & 0.09 & 1.54 & 0.55 & 251.20 & 0.23 & 0.07 & \\
\hline E & 36 & 1.19 & 11.96 & 0.36 & 0.06 & 1.11 & 1.60 & 463.43 & 0.24 & 0.13 & \\
\hline $\mathrm{CV} \%$ & & 4.44 & 9.10 & 4.14 & 18.71 & 2.33 & 6.004 & 11.11 & 13.02 & 4.77 & \\
\hline
\end{tabular}

${ }^{*}$ and ${ }^{* *}$ : Significant at $5 \%$ and $1 \%$ levels, respectively

Tab. 2. Interaction between different levels of water stress and different concentration of ascorbic acid

\begin{tabular}{|c|c|c|c|c|c|c|c|c|c|c|c|}
\hline $\begin{array}{l}\text { Water } \\
\text { stress }\end{array}$ & $\begin{array}{l}\text { Ascorbic } \\
\text { acid Con- } \\
\text { centration }\end{array}$ & $\begin{array}{c}\text { Stem dry } \\
\text { weight } \\
\text { (g) }\end{array}$ & $\begin{array}{l}\text { Height } \\
(\mathrm{cm})\end{array}$ & $\begin{array}{c}100 \text { grain } \\
\text { weight }(\mathrm{g})\end{array}$ & $\begin{array}{c}\text { Diameter } \\
\text { of cob } \\
(\mathrm{mm})\end{array}$ & $\begin{array}{l}\text { Number } \\
\text { of grain } \\
\text { in row }\end{array}$ & $\begin{array}{l}\text { Length of } \\
\text { infertile } \\
\text { grains }(\mathrm{cm})\end{array}$ & $\begin{array}{c}\text { Ear } \\
\text { diameter } \\
(\mathrm{mm})\end{array}$ & $\begin{array}{c}\text { Ear } \\
\text { length } \\
(\mathrm{cm})\end{array}$ & $\begin{array}{c}\text { Ear } \\
\text { weight } \\
\text { (g) }\end{array}$ & $\begin{array}{l}\text { Oil } \\
(\%)\end{array}$ \\
\hline \multirow{4}{*}{ No stress } & $0 \mathrm{mgl}^{-1}$ & $123.47 \mathrm{bc}$ & $167.88 \mathrm{a}$ & $30.23 c$ & $24.93 \mathrm{bc}$ & $43.20 \mathrm{a}$ & $0.83 c$ & $46.10 \mathrm{~b}$ & $21.53 \mathrm{~cd}$ & $222.53 \mathrm{abc}$ & $3.59 \mathrm{~cd}$ \\
\hline & $50 \mathrm{mgl}^{-1}$ & $118.82 \mathrm{bc}$ & $164.33 a$ & $30.30 \mathrm{c}$ & $26.20 \mathrm{ab}$ & $43.08 \mathrm{a}$ & $0.75 \mathrm{c}$ & $46.08 \mathrm{~b}$ & $22.20 \mathrm{bc}$ & $226.05 \mathrm{ab}$ & $3.37 \mathrm{~cd}$ \\
\hline & $100 \mathrm{mgl}^{-1}$ & $125.40 \mathrm{~b}$ & $162.11 \mathrm{a}$ & $30.78 c$ & $25.88 \mathrm{ab}$ & $42.90 \mathrm{a}$ & $0.90 \mathrm{c}$ & $47.96 \mathrm{a}$ & $22.10 b c$ & $224.43 \mathrm{ab}$ & $3.24 \mathrm{~d}$ \\
\hline & $150 \mathrm{mgl}^{-1}$ & $150.88 \mathrm{a}$ & & & & & & $48.33 a$ & & $241.43 \mathrm{a}$ & $3.21 \mathrm{~d}$ \\
\hline \multirow{4}{*}{$\begin{array}{l}\text { Vegetati- } \\
\text { ve stress }\end{array}$} & $0 \mathrm{mgl}^{-1}$ & $73.13 \mathrm{f}$ & $127.22 \mathrm{~d}$ & $24.70 \mathrm{e}$ & $24.23 c$ & $33.56 \mathrm{c}$ & $1.63 \mathrm{~b}$ & $45.03 \mathrm{bcd}$ & $18.76 \mathrm{e}$ & $158.38 \mathrm{f}$ & $3.52 \mathrm{~cd}$ \\
\hline & $50 \mathrm{mgl}^{-1}$ & 103.85bcde & $141.50 \mathrm{bc}$ & $26.75 d$ & $25.45 b c$ & $41.51 \mathrm{a}$ & $1.41 \mathrm{~b}$ & $45.70 \mathrm{bc}$ & $21.21 \mathrm{~cd}$ & $211.07 \mathrm{bcd}$ & $3.21 \mathrm{~d}$ \\
\hline & $100 \mathrm{mgl}^{-1}$ & $98.15 \mathrm{cdef}$ & $142.77 b$ & $26.66 \mathrm{~d}$ & $25.45 b c$ & $39.16 \mathrm{ab}$ & $1.50 \mathrm{~b}$ & $45.56 \mathrm{bc}$ & 20.40de & $195.48 \mathrm{~cd}$ & $3.36 \mathrm{~cd}$ \\
\hline & $150 \mathrm{mgl}^{-1}$ & $118.26 \mathrm{bc}$ & $148.89 \mathrm{~b}$ & $34.83 b$ & $25.80 \mathrm{ab}$ & $40.38 \mathrm{a}$ & $1.36 \mathrm{~b}$ & $46.33 b$ & $23.40 \mathrm{~b}$ & $211.77 \mathrm{bcd}$ & $3.54 \mathrm{~cd}$ \\
\hline \multirow{4}{*}{$\begin{array}{l}\text { Reproduc- } \\
\text { tive stress }\end{array}$} & $0 \mathrm{mgl}^{-1}$ & $80.22 \mathrm{ef}$ & $142.44 b c$ & $19.76 \mathrm{~g}$ & $18.80 \mathrm{e}$ & $26.76 \mathrm{~d}$ & $2.60 \mathrm{a}$ & $37.93 \mathrm{f}$ & $16.93 \mathrm{f}$ & $124.03 \mathrm{~g}$ & $5.62 \mathrm{a}$ \\
\hline & $50 \mathrm{mgl}^{-1}$ & $109.45 \mathrm{bcd}$ & $141.44 \mathrm{bc}$ & $22.96 \mathrm{f}$ & $22.13 \mathrm{~d}$ & $35.7 \mathrm{bc}$ & $1.65 \mathrm{~b}$ & $44.61 \mathrm{~cd}$ & 20.00de & $186.38 \mathrm{de}$ & $5.00 \mathrm{~b}$ \\
\hline & $100 \mathrm{mgl}^{-1}$ & $108.01 \mathrm{bcd}$ & $141.72 \mathrm{bc}$ & $24.46 \mathrm{ef}$ & $24.01 \mathrm{c}$ & $33.41 \mathrm{c}$ & $1.61 \mathrm{~b}$ & $43.93 \mathrm{de}$ & $19.46 \mathrm{e}$ & $158.70 \mathrm{f}$ & $3.98 \mathrm{c}$ \\
\hline & $150 \mathrm{mgl}^{-1}$ & $88.65 \mathrm{def}$ & $130.99 \mathrm{~cd}$ & $26.40 \mathrm{~d}$ & $25.05 b c$ & $32.61 \mathrm{c}$ & $1.45 \mathrm{~b}$ & $43.18 \mathrm{e}$ & $20.40 \mathrm{de}$ & $162.90 \mathrm{ef}$ & $4.011 \mathrm{c}$ \\
\hline
\end{tabular}

Means with similar letter are not significant at the $5 \%$ probability level (Duncan $5 \%$ )

while there was not significant difference between water it's related to water status imbalance, reduce of cell division stress before and after flowering in these traits. This event and growth of different organs and reduction in photosyn- 
48

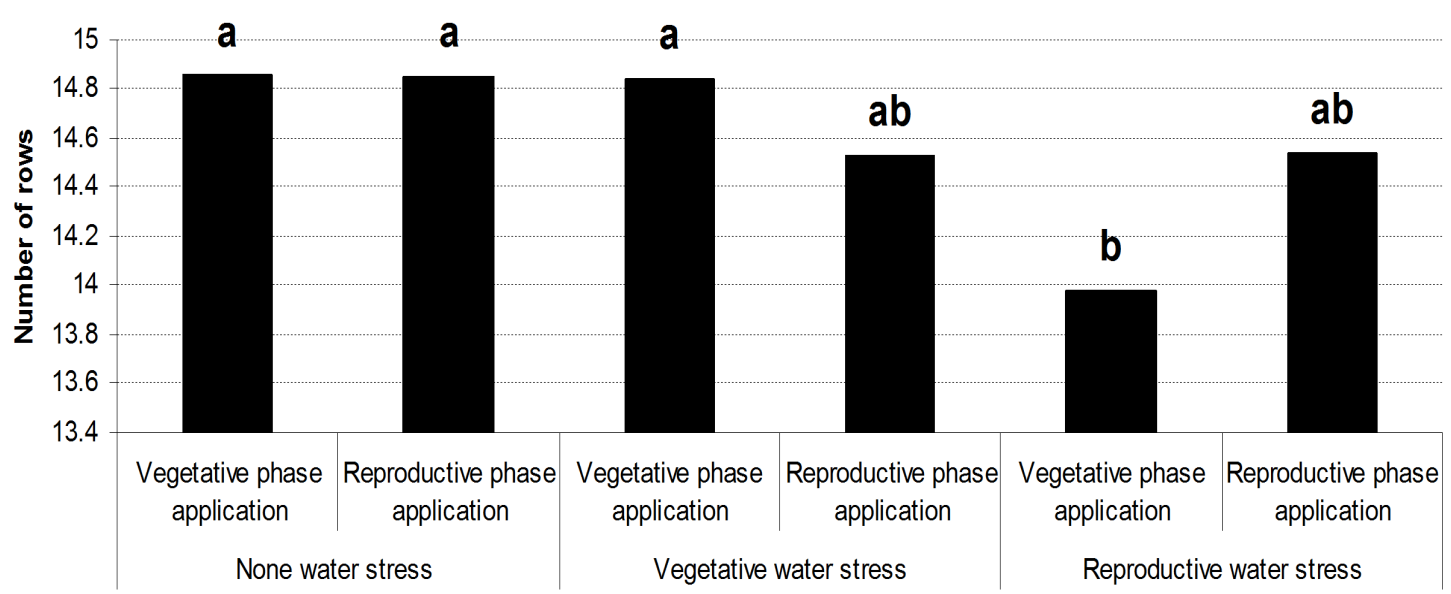

Interaction between time of water stress and time of ascorbic acid application

Fig. 1. Interaction between water stress and time of ascorbic acid application

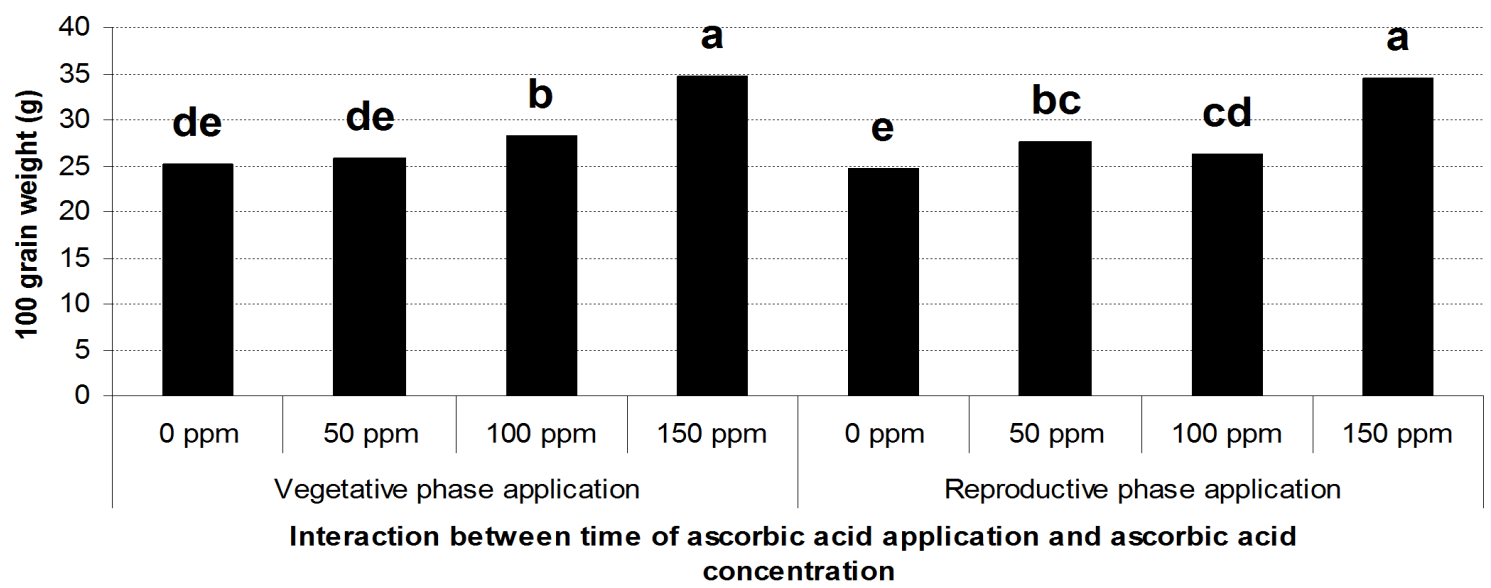

Fig. 2. Interaction between time and concentration of ascorbic acid application

Tab. 3. Main effects of water stress, time of foliar application and concentration of ascorbic acid

\begin{tabular}{|c|c|c|c|c|c|c|c|c|c|}
\hline \multicolumn{2}{|c|}{ Treatments } & $\begin{array}{c}\text { Leaf dry } \\
\text { weight }(\mathrm{g})\end{array}$ & $\begin{array}{l}\text { Stem fresh } \\
\text { weight }(\mathrm{g})\end{array}$ & $\begin{array}{l}\text { Leaf fresh } \\
\text { weight }(\mathrm{g})\end{array}$ & $\begin{array}{c}\text { Leaf area } \\
\text { index }\end{array}$ & $\begin{array}{l}\text { Number } \\
\text { of leaves }\end{array}$ & $\begin{array}{c}\text { Grain } \\
\text { yield }\end{array}$ & $\begin{array}{c}\text { Cob } \\
\text { weight }(\mathrm{g})\end{array}$ & $\begin{array}{l}\text { Protein } \\
(\%)\end{array}$ \\
\hline \multirow{3}{*}{ Water stress } & No stress & $45.25 \mathrm{a}$ & $418.42 \mathrm{a}$ & $142.90 \mathrm{a}$ & $5106.8 \mathrm{a}$ & $12.88 \mathrm{a}$ & $320.28 \mathrm{a}$ & $43.61 \mathrm{a}$ & $7.56 \mathrm{~b}$ \\
\hline & $\begin{array}{l}\text { Before flowering } \\
\text { stress }\end{array}$ & $39.62 \mathrm{~b}$ & $353.11 \mathrm{~b}$ & $116.25 a$ & $3984 b$ & $11.02 \mathrm{a}$ & $267.70 \mathrm{~b}$ & $35.89 \mathrm{~b}$ & $7.42 b$ \\
\hline & $\begin{array}{l}\text { After flowering } \\
\text { stress }\end{array}$ & $40.72 b$ & 383.39ab & $116.48 \mathrm{a}$ & $4611.7 \mathrm{a}$ & $11.26 \mathrm{a}$ & $198.28 \mathrm{c}$ & $28.60 \mathrm{c}$ & $8.20 \mathrm{a}$ \\
\hline \multirow{2}{*}{$\begin{array}{l}\text { Time of foliar } \\
\text { application }\end{array}$} & $\begin{array}{l}\text { Before flowering } \\
\text { application }\end{array}$ & $41.93 \mathrm{a}$ & $383.69 a$ & $125.66 \mathrm{a}$ & $4530 \mathrm{a}$ & $11.63 \mathrm{a}$ & $261.82 \mathrm{a}$ & $34.88 \mathrm{a}$ & $7.71 \mathrm{a}$ \\
\hline & $\begin{array}{l}\text { After flowering } \\
\text { application }\end{array}$ & $41.79 \mathrm{a}$ & $386.25 a$ & $124.75 a$ & $4605 a$ & $11.81 \mathrm{a}$ & $269 a$ & $37.18 \mathrm{a}$ & $7.74 \mathrm{a}$ \\
\hline \multirow{4}{*}{$\begin{array}{c}\text { Ascorbic acid } \\
\text { Concentration } \mathrm{mgl}^{-1}\end{array}$} & 0 & $38046 b$ & $356.56 \mathrm{~b}$ & $100.11 b$ & $4052.3 b$ & $12.62 \mathrm{a}$ & $230.07 b$ & $31.52 \mathrm{~b}$ & $7.61 \mathrm{a}$ \\
\hline & 50 & $42.73 \mathrm{a}$ & $402.74 a$ & $130.40 \mathrm{a}$ & $4625.8 \mathrm{a}$ & $11.51 \mathrm{a}$ & $283.46 a$ & $37.71 \mathrm{a}$ & $7.73 a$ \\
\hline & 100 & $43.86 a$ & $403.74 a$ & $135.12 \mathrm{a}$ & $4698.4 a$ & $11.40 \mathrm{a}$ & $266.22 \mathrm{a}$ & $36.07 \mathrm{a}$ & $7.74 \mathrm{a}$ \\
\hline & 150 & $42.39 \mathrm{a}$ & $376.85 \mathrm{ab}$ & $135.20 \mathrm{a}$ & $4893.4 a$ & $11.35 \mathrm{a}$ & $281.92 \mathrm{a}$ & $38.82 \mathrm{a}$ & $7.82 \mathrm{a}$ \\
\hline
\end{tabular}

Means with similar letter are not significant at the $5 \%$ probability level (Duncan 5\%)

thesis rate (Boyer and McPherson, 1976). Effect of water deficit stress is associated with photosynthesis and growth reduction as reduced photosynthesis, reduces dry matter production and growth (Mwanamwenge et al., 1999).
Leaf area was affected by water stress at vegetative stage but water stress after flowering had not significant difference on leaf area (Tab. 3) thus, water stress at vegetative stage is determinative of leaf area development. Water 
stress deficit has less influence on yield at vegetative stage than water stress occurrence at reproductive stage. Nevertheless, stem and leaf growths are more sensitive to water stress (Hsiano, 1973). Leaf area expansion is depends on agronomic practices, climate and genetic. Water stress reduces leaf area through reducing of cell division and growth. Richie et al. (1992) have been reported that water stress decreases leaf area index and final yield (Richie $e t$ al., 1992)

It observed that plant height was decreased in plants that were exposure to water stress (Tab. 3). Stem in corn acts as a source of movable and non-structural carbohydrate after flowering. If photosynthesis impaired in the initial stages of grain filling, the carbohydrates act as a source of grain growth. In fact, stem plays important role in assimilates transport and storage (Fairy and Daynard, 1978). Denmead and Shaw (1960) showed that water stress reduces plant height, cob height and leaf area index. In this study different levels of water stress had different effect on grain yield, grain weight and cob weight. So that the maximum and minimum weights were achieved from without stress plots and stressed plots after flowering, respectively (Tab. 3). Water deficit stress decreases number of grains and 1000 grain weight just before the emergence of tassel (Pandey et al., 2000). Mirhadi and Kobayashi, (1979) have been reported that water stress decreased ear weight, number of grains in ear and 1000 grain weight at initial of seed filling stage.

Water stress reduces pollen production or decreases seed fertility due to silk damage and finally led to reduced of yield (Bassetti and Westgate, 1993). Water stress significantly decreased cob diameter when plants were stressed after tassel appearance while water stress induction had not any effect on it and the results were equal with unstressed plants (Tab. 3).

Number of grain in rows as important factors which were affected by water stress; were significantly decreased, especially when water stress occurred after flowering stage.

Water stress before silking stage prevents the development of female flowers and leads to increase infertile seeds while stress after pollination or seed filling decreases grain weight. Silking and seed filling stages are two most sensitive stages to water stress and occurrence of water stress at these stages decreases grain number (Frey, 1982).

Also it was observed that cob diameter, ear length and cob weight were decreased due to water stress at vegetative stage and this decrease was stronger in those plots that were stressed after tasseling stage (Tab. 3).

Water stress at the time of emergence of tassel not only decreases plant ability to flowering and pollination, but also it can decrease pollen longevity (Schussler and Westgate, 1991).

The highest amount of infertile seeds was observed in those plots which were stressed after tasseling stage; however, water stress increased infertile seeds at before tassel appearance in compare with control plants. Water deficits stress decreases pollen production and fertility at reproductive stage and also reduces seed fertilization and thus reduces the number of grains (Setter et al., 2001).

Time of ascorbic acid foliar application was not significant except in length of infertile seeds (Tab. 1). Length of infertile seeds was decreased when ascorbic acid was applied after tassel appearance (Tab. 2). It seems that ascorbic acid increases fertilization and seed production. Grain number was reduced in cereal under condition of low water potential which is occurred due to lack of fertilization. Decrease of pollens in the pollination stage by water stress occurs in microsporogenesis phase (Saini and Westgate, 2000). Ascorbic acid as an effective agent in growth and cell division increases pollen production and fertility ( $\mathrm{Pi}$ gnocchi and Foyer, 2003). Sensitivity of pollen grains is less than female florets and often floret death is one of the limitative factors for the grain number that causes embryo abortion in the ovaries (Bassetti and Westgate, 1993).

Effect of ascorbic acid concentrations was significant in most traits but number of leaves, height and protein percentage were not affected by ascorbic acid (Tab. 3). Comparison of means showed that application of 150 $\mathrm{mgl}^{-1}$ ascorbic acid at vegetative stage increased stem dry weight in compare with control treatment (sprayed by water). Also, application of $50 \mathrm{mgl}^{-1}$ ascorbic acid at reproductive stage on stressed plants increased stem dry weight than control treatment. Ascorbic acid foliar application $\left(100 \mathrm{mgl}^{-1}\right)$ at vegetative growing stage increased leaf dry weight in non stress plants, but there was not significant difference between 100 and $150 \mathrm{mgl}^{-1}$ treatments (Tab. 2). As for results of leaf fresh weight, ascorbic acid foliar application increased leaf fresh weight than control treatments when plants were at vegetative stage and normal conditions (Tab. 2). Also, leaf fresh weight was increased when ascorbic acid was applied on stressed plant before tassel appearance (Tab. 2). Similar results were achieved when ascorbic acid was applied at reproductive stage on stressed plants at vegetative stage (Tab. 2). It seems that ascorbic acid causes cell division and following increasing of growth. In addition, ascorbic acid as antioxidant molecule alleviates adverse effects of water stress. It's reported that acidification of apoplastic space accelerates of cell division. On the other hand, the $\mathrm{pH}$ of the apoplastic space correlated with the growth rate of the tissue (Pignocchi and Foyer, 2003). Grain weight was increased due to 150 $\mathrm{mgl}^{-1}$ ascorbic acid foliar application at vegetative and reproductive stages on none stressed and stressed plants before flowering stage while in stressed plants, at reproductive stage, the highest grain weight was observed in treated plants with 100 and $150 \mathrm{mgl}^{-1}$ ascorbic acid at vegetative stage (Tab. 2). It seems that ascorbic acid increased resistance to stress. Grain weight increasing can be due to increase of photosynthesis and assimilates transport to the grains followed by reducing of drought stress effects attributed to ascorbic acid. 
50

Foliar application after the emergence of tassels and under normal condition (none stress) had significant effect on cob weight than lack of ap plication (Tab. 2). Similar results were obtained when ascorbic acid was applied at 50 and $100 \mathrm{mgl}^{-1}$ concentrations on those plants were stressed before flowering. While ascorbic acid foliar application increased cob diameter at both of growth stages in those plots were stressed after flowering. Numbers of grains in row were affected by ascorbic acid application at reproductive stage (Tab. 2). Ascorbic acid neutralizes reactive oxygen species generated by water stress.

The highest infertile seeds were achieved from those plots which were stressed after tasseling and without ascorbic acid (Tab. 2). Ascorbic acid foliar application decreased length of infertile seeds. The results showed that, 100 and $150 \mathrm{mgl}^{-1}$ ascorbic acid increased ear diameter when it was applied after tassel emergence (Tab. 2). The length of ear was affected by $150 \mathrm{mgl}^{-1}$ ascorbic acid under normal condition (none stress). Similar results were observed in stressed plants (Tab. 2). The highest oil percentage was achieved from stressed plants at reproductive stage while ascorbic acid $\left(100\right.$ and $\left.150 \mathrm{mgl}^{-1}\right)$ decreased it (Tab. 2). Protein percentage increased due to $150 \mathrm{mgl}^{-1}$ ascorbic acid foliar application (Tab. 2). It's reported that ascorbic acid scavenges reactive oxygen species and prevents protein oxidation and degradation (Noctor and Foyer, 1998). Protein synthesis is one of the most important processes in plants which affects by water stress (Bradford and Hsiao, 1982).

\section{References}

Asada, K. (1999). The water-water cycle in chloroplasts: scavenging of active oxygen's and dissipation of excess photons. Annu Rev. of Plant Physiol and Plant Mol Biol. 50:601-639.

Bassetti, P., and M. E. Westgate (1993). Water deficit affects respectively of maize silks. Crio Sci. 33:279-28.

Boyer, J. S. and H. G. McPherson (1976). Physiology of water deficits in cereal grains, p.321-339. In: IRRI Eds. Climate and Rice. IRRI, Los Banos, Philippines.

Denmead, O. T. and R. H. Shaw (1960). The effect of soil moisture stress at different stage of growth on the development and yield of corn. Agron. J. 52:272-274.

Edmeades, G. O., J. Bolaòos, M. Hernandez and S. Bello (1993). Causes for silk delay in a lowland tropical maize population. Crop Sci. 33:1029-1035.

Fairy, N. A. and T. B. Daynard (1978). Quantitative distribution of assimilates in component organ of maize during reproductive growth. Can J. Plant Sci. 58:709-717.

Fischer, K. S. and F. E. Palmer (1984). Tropical maize, p. $213-$ 248. In: Goldsworthy P. R. and N. M. Fischer Eds. The Physiology of Tropical Field Crops. Wiley, New York.

Foyer, C. H., J. Harbinson (1994). Oxygen metabolism and the regulation of photosyntetic electron transport. In: C. H. Foyer and P. M. Mulhneaux (Eds.). Causes of photooxidative stress and amelioration of defense systems in plants. Boca
Raton, FL: CRC Press p.1-42.

Frey, N. M. (1982). Dry matter accumulation in kernels of maize. Crop Sci. 21:118-122.

Hsiano, T. C. (1973). Plant responses to water stress. Annu Rev Plant Physiol. 24:519-570.

McPherson, H. G. and J. S. Boyer (1977). Regulation of grain yield by photosynthesis in maize subjected to a water deficiency. Agron J. 69:714-718.

Mirhadi, M. J. and Y. Kobayashi (1979). Study on productivity of grain sorghum. 2. Effect on wilting treatment at different stages of growth on the development, nitrogen uptake and yield of irrigated sorghum. Japanese's. J. Crop Sci. 48(4):531542.

Munne-Bosch, S. and L. Alegre (2000). Changes in carotenoids, tochopherols and diterpenes during drought and recovery and the biological significance of chlorophyll loss in Rosmarinus officianalis planta. Plants 210:925-931.

Mwanamwenge, J., S. P. Loss, K. H. M. Siddique, P. S. Cocks (1999). Effect of water stress during floral initiation, flowering and podding on the growth and yield of faba bean (Vicia faba L.). Eur. J. Agron. 11:1-11.

Noctor, G. and C. H. Foyer (1998). Ascorbate and glutathione: Keeping active oxygen under control. Annu Rev of plant physiol and plant Mol Biol. 49:249-279.

Otegui, M.E. (1995). Prolificacy and grain yield components in modern Argentinean maize hybrids. Maydica 40:371-376.

Pandey, R. K., J. W. Maranville and A. Admou (2000). Deficit irrigation and nitrogen effects of maize in a Sahelian environment. I: Grain yield and yield components. Agric. Water Manage. 46:1-13.

Pignocchi, C. and C. H. Foyer (2003). Apoplastic ascorbate metabolism and its role in the regulation of cell signaling. Curr Opin in Plant Biol. 6:379-389.

Richie, S. W., J. J. Hanway and G. O. Benson (1992). How a corn plant develops. Special Report No. 48. Iowa State University p.21.

Rochefort, F. I. and L. Woodward (1992). Effects of climate change and a doubling of $\mathrm{CO}_{2}$ on vegetation diversity, J. Exp. Bot. 43:1169-1180.

Saini, H. S. and M. E. Westgate (2000). Reproductive development in grain crops during drought. Advances in Agronomy 68:59-96.

Schussler, J. R. and M. E. Westgate (1991). Maize kernel set at low water potential: I. Sensitivity to reduced assimilates during early kernel growth. Crop Sci. 31:1189-1195.

Setter, T. L., B. Flannigan and J. Melkonian (2001). Loss of kernel set due to water deficit and shade in maize. Crop Sci. 41:1530-1540.

Tollenaar, M. (1977). Sink-source relationships during reproductive development in maize: A review. Maydica 23:49-75.

Tsugane, K., K. Koboyashi, Y. Niwa, Y. Ohba, K. Wada and H. Koboyashi (1999). A recessive Arabidobsis mutant that grows photoautotrophically under salt stress shows enhancedactive oxygen detoxification. The Plant Cell 11:1195-1206. 